\title{
Сучасні візуалізаційні технології у діагностиці первинних інтраабдомінальних ускладнень у хворих
}

\author{
В.В. Скиба 1, 3, 4, В.Ф. Рибальченко 2,3, О.В. Іванько, 3,4, А. Дар Ясін ${ }^{3}$ \\ 'Національний медичний університет імені О.О. Богомольця, Київ, Україна \\ ${ }^{2}$ Національний університет охорони здоров'я України імені П.Л. Шупика, Київ, Україна \\ ${ }^{3}$ Приватний вищий навчальний заклад «Київський медичний університет», Київ, Україна \\ ${ }^{4}$ Комунальне некомерційне підприємство «Київська міська клінічна лікарня № 1», Київ, Україна
}

Анотація. Мета: покращити результати лікування хворих із первинними інтраабдомінальними ускладненнями за рахунок впровадження новітніх інформативних методів візуалізації. Об'єкт і методи дослідження. У клініці кафедри хірургічних хвороб № 1 на базі Центру хірургії Київської міської клінічної лікарні № 1 в період 2006-2019рр. знаходився на лікуванні 191 пацієнт з первинними інтраабдомінальними інфільтратами, абсцесами і рідинними утвореннями. Вік пацієнтів становив 16-85 років. Хворі розділені на дві групи: контрольна (2006-2012рр.) - 102 (53,4\%) і досліджувана (2013-2019 рр.) - 89 (46,6\%) хворих. Методи обстеження: рентгенографія, ультразвукове дослідження (УзД), комп'ютерна томографія (КТ). Результати. Причинами виникнення первинних інтраабдомінальних ускладнень були ускладнені форми апендициту - у 74 (38,7\%), перфоративна виразка шлунка та дванадцятипалої кишки - у 48 (25,1\%), ускладнені форми холециститу - у 69 (36,1\%) пацієнтів. У контрольній групі проведена оглядова рентгенографія органів черевної та грудної порожнини з клінічними ознаками перфоративної виразки шлунка і дванадцятипалої кишки, а також хворим з підозрою на непрохідність кишечнику на тлі запального процесу. Аналіз даних у 26 хворих показав, що в 6 з них не встановлено вільного повітря в черевній порожнині. У досліджуваній групі хворих проводили вимірювання шкірної температури передньої черевної стінки у 48 з 89 хворих, з яких у 39 вона була підвищена на 2-3 ${ }^{\circ} \mathrm{C}$. 3а даними УзД органів черевної порожнини, встановлено прямі і непрямі ознаки запального процесу. УзД проведено в 81389 хворих, з яких при деструктивному апендициті - у 35, при деструктивному холециститі - у 32 і при перфоративній виразці шлунка і дванадцятипалої кишки - у 14. Результати показали, що візуалізація встановлена у 68 з 72 пацієнтів, з яких апендикулярний абсцес у 15 з 16 і апендикулярний інфільтрат - у 18 з 19. Локалізація червоподібного відростка, за даними УзД, типова у 22, медіальне розташування - у 6 і підпечінкове - у 7 хворих. УзД жовчного міхура проведено у 32 хворих, встановлені зміни, які вказували на наявність запального процесу. Оглядова рентгенографія проведена у 22 хворих з перфоративною виразкою шлунка і дванадцятипалої кишки, з яких вільне повітря виявлено у 17 пацієнтів. КТ проведена у 16 хворих. Висновки. 3 метою верифікації інтраабдомінальної патології шкірна термометрія була інформативною у 39 з 48 хворих. При верифікації перфоративної виразки шлунка і дванадцятипалої кишки у 17 з 22 хворих оглядова рентгенографія була неінформативною, що потребувало проведення КТ. УзДдослідження органів черевної порожнини було інформативним у 48,1-73,5\% випадків залежно від патології (деструктивний апендицит, деструктивний холецистит) і розвитку ускладнень з чутливістю 58-84,5\% і специфічністю 69-89,3\%, а розбіжності пов'язані з вдосконаленням методики обстеження.

Ключові слова: апендицит, холецистит, перфоративна виразка шлунка та дванадцятипалої кишки, діагностика, ультразвукова діагностика, рентгенографія, комп'ютерна томографія, магнітно-резонансна томографія.

\section{Вступ}

Абдомінальний біль змушує хворих звертатися перш за все до відділення невідкладної допомоги, що становить 7-10\% всіх випадків госпіталізації. Однак верифікація абдомінального болю, особливо хірургічного походження, до сьогодні $\epsilon$ складною клінічною проблемою, оскільки залежить від своєчасності діагностики та їі якості і впливає на кількість можливих ускладнень. За даними літератури, інтраабдомінальні хірургічні захворювання ускладнюються формуванням абсцесів або інфільтратів у $20-25 \%$ хворих [1, 2].

Зазвичай частота ускладнень напряму пов'язана із запізнілою госпіталізацією. В Україні серед пацієнтів, госпіталізованих пізніше, ніж через 24 год від початку захворювання, чітко простежується підвищена летальність. Серед нозологічних форм із запізнілою госпіталізацією: деструктивний апендицит - 20,9\% випадків (післяопераційна летальність - 0,15\%), гострий холецистит - 39,2\% (19,7\%), перфоративна виразка шлунка та дванадцятипалої кишки - 12,5\% (13,73\%), гостра непрохідність кишечнику на тлі гриж черевної стінки - $5 \%$ ( $1 / 3$ усіх випадків) $[1,2]$.

На результати післяопераційної летальності суттєво впливають характер ускладнень та вік пацієнтів. Так, за даними S. Di Saverio та співавторів (2020), перфорація при гострому апендициті становить $16-40 \%, \epsilon$ характерною особливістю для пацієнтів молодого віку (40-57\%) і осіб віком >50 років
(55-70\%) зі смертністю $\leq 0,1$ та 0,6\% відповідно [3]. Особливо висока летальність характерна для деструктивного апендициту (5-8\%, переважно у хворих віком >65 років), зазвичай на тлі розвитку інтраабдомінальних ускладнень (перфорація, абсцедування) із частотою 18-70\%. Своєчасне їх виявлення значною мірою залежить від проведення ультразвукової діагностики (УЗД) та комп'ютерної томографії (КТ) на етапі госпіталізації $[3,4]$.

Холецистит - друга за поширеністю причина гострого абдомінального болю, яку, за даними різних авторів, виявляють у 5-10\% хворих. Так, за даними М. Pisano та співавторів (2020), гострий конкрементний холецистит виявляють у 10-15\% пацієнтів [5]. За даними J.L. Huffman, S. Schenker (2010), на некалькульозний холецистит припадає 10\% всіх випадків гострого запалення жовчного міхура, а сукупна захворюваність та смертність становлять 24 та 3\% відповідно [6]. У цих випадках основним діагностичним методом $\epsilon$ УЗД органів черевної порожнини.

За даними А. Tarasconi та співавторів (2020), поширеність перфоративної виразки шлунка та дванадцятипалої кишки в загальній популяції становить 5-10\% з частотою розвитку ускладнень 10-20\%. Занепокоєння викликає низька інформативність загальновизнаних методів обстеження (оглядової рентгенографії органів черевної порожнини та грудної клітки): у 15\% госпіталізованих вона неінформативна $[7,8]$. 
Впровадження останніми роками новітніх методів візуалізації при гострих захворюваннях органів черевної порожнини дає змогу значно підвищити якість діагностики. Серед них - метод УЗД, висока інформативність і специфічність якого доведена при багатьох гострих захворюваннях черевної порожнини. У $90 \%$ випадків УЗД $\epsilon$ базовим методом першочергового клінічного діагностичного підходу, і лише у складних клінічних випадках постає потреба у проведенні КТ-обстеження або магнітно-резонансної томографії (МРТ), особливо при підозрі на перфорацію порожнистого органу [3, 5, 7, 9]. Застосування контрастної речовини значно підвищує специфічність та інформативність променевої діагностики в ургентній хірургії органів черевної порожнини до 90,7 та 97,4\% відповідно [10]

3 метою покращення діагностики та моніторингу перебігу післяопераційного періоду пацієнтів із гострою хірургічною патологією органів черевної порожнини розроблено та запроваджено методику вимірювання шкірної температури передньої черевної стінки із застосуванням термометрії інфрачервоного спектру та її коливання порівняно з аксилярною температурою. На винахід «Термометрична панель передньої черевної стінки та прогностичний аксилярно-абдомінальний коефіцієнт» отримано патент. Метод простий у виконанні, інформативний, не потребує спеціальної підготовки хворого і може проводитися лікарем приймального відділення [11-14].

Таким чином, вчасна діагностика інтраабдомінальних ускладнень (абсцесів, інфільтратів, рідинних утворень) залишається актуальною клінічною проблемою, незважаючи на значну кількість діагностичних підходів, і потребує суворого дотримання послідовності їх застосування з огляду на ймовірність розвитку несприятливих подій при несвоєчасному виявленні ускладнень.

Мета роботи: покращити результати лікування хворих із первинними інтраабдомінальними ускладненнями за рахунок впровадження новітніх інформативних методів візуалізації.

\section{0б'єкт і методи дослідження}

У дослідження залучений 191 пацієнт із первинними інтраабдомінальними інфільтратами, абсцесами та рідинними утвореннями черевної порожнини, який проходив лікування у клініці кафедри хірургічних хвороб № 1 Центру хірургії Київської міської клінічної лікарні № 1 в період 2006-2019рр. Вік пацієнтів становив 16-85 років; чоловіків - 94 (49,2\%), жінок - 97 (50,8\%). У дослідження включено пацієнтів із первинними пухкими інфільтратами, абсцесами та рідинними утвореннями. Пацієнтів із щільними інфільтратами у дослідження не включали, так як в них використовували іншу методику лікування.

Залежно від періоду госпіталізації пацієнти розділені на дві групи: контрольна (2006-2012рр.) - 102 (53,4\%) та досліджувана (2013-2019рр.) - $89(46,6 \%)$ пацієнтів. Обгрунтуванням для розділення на групи було використання новітніх візуалізаційних технологій з метою діагностики (УЗД + кольорове дуплексне картування, КТ, МРТ, термометрія) та новітніх загальновизнаних та вдосконалених методик хірургічного лікування у досліджуваній групі.

При госпіталізації проводили загальноклінічне дослідження крові та сечі в усіх хворих. Рентгенологічне дослідження (оглядова рентгенографія органів черевної порожнини у вертикальному та поліпозиційному положенні) проведено у 129 пацієнтів, КТ - у 16, УзД органів черевної порожнини - у 81, дослідження стану кровотоку утворення (кольорове дуплексне картування) - у 43, еластографію - у 23, шкірну термометрію передньої черевної стінки - у 39.

\section{Результати}

Причинами виникнення первинних інфільтративних та абсцедуючих утворень черевної порожнини були ускладнені форми апендициту - у 74 (38,7\%), перфоративна виразка шлунка та дванадцятипалої кишки - у 48 (25,1\%), ускладнені форми холециститу - у 69 (36,1\%) пацієнтів. Розподіл хворих за нозологічними групами представлено в таблиці.
Таблиця Розподіл хворих досліджуваних груп

\begin{tabular}{|c|c|c|c|c|c|}
\hline \multirow{3}{*}{ Ускладнення } & \multirow{3}{*}{ 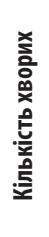 } & \multicolumn{4}{|c|}{ Група } \\
\hline & & \multicolumn{2}{|c|}{$\begin{array}{c}\text { Контрольна } \\
(2002-2012 \text { pp.), } \\
\mathrm{n}=102\end{array}$} & \multicolumn{2}{|c|}{$\begin{array}{c}\text { Досліджувана } \\
\text { (2013-2019 рр.), } \\
\text { n=89 }\end{array}$} \\
\hline & & $\begin{array}{l}\text { Абсцес, } \\
\mathrm{n}(\%)\end{array}$ & $\begin{array}{l}\text { Інфільтрат, } \\
\text { n (\%) }\end{array}$ & $\begin{array}{l}\text { Абсцес, } \\
\mathrm{n}(\%)\end{array}$ & $\begin{array}{l}\text { Інфільтрат, } \\
\text { n (\%) }\end{array}$ \\
\hline Деструктивний апендицит & 74 & $32(16,7)$ & $7(3,7)$ & $16(8,4)$ & $19(9,9)$ \\
\hline Деструктивний холецистит & 69 & $35(18,3)$ & $2(1,0)$ & $24(12,6)$ & $8(4,2)$ \\
\hline $\begin{array}{l}\text { Перфоративна виразка шлунка } \\
\text { та дванадцятипалої кишки }\end{array}$ & 48 & $8(4,2)$ & $18(9,4)$ & $20(10,5)$ & $2(1,0)$ \\
\hline Загалом & 191 & $75(39,3)$ & $27(14,1)$ & $60(31,4)$ & $29(15,2)$ \\
\hline
\end{tabular}

Основними візуалізаційними методами обстеження хворих в контрольній групі були оглядова рентгенографія органів черевної та грудної порожнини, яку проводили пацієнтам з клінічними ознаками перфоративної виразки шлунка та дванадцятипалої кишки, а також хворим із підозрою на непрохідність кишечнику на тлі запального процесу. УЗД органів черевної порожнини в цій групі проведено у 12 хворих; це був початок впровадження методу в ургентній хірургії. Аналіз ретроспективних даних у 26 (13,61\%) хворих з перфоративною виразкою шлунка та дванадцятипалої кишки показав, що у 6 пацієнтів не встановлено вільного повітря в черевній порожнині та тільки після проведення фіброгастродуоденоскопії виявлена перфорація та вільне повітря в черевній порожнині, що підтверджено повторним дослідженням. Проведене рентгенологічне дослідження у 14 з 76 хворих з клінічною картиною непрохідності кишечнику на тлі запального процесу, причиною якої був деструктивний апендицит у 5 з 39 та деструктивний холецистит - у 9337 пацієнтів. Таким чином, в контрольній групі хворих діагноз ґрунтувався власне на досвіді хірурга за даними анамнезу, клінічного і лабораторного обстеження, що в подальшому підтверджено інтраопераційно.

У досліджуваній групі хворих у приймальному відділенні при огляді проводили вимірювання шкірної температури передньої черевної стінки у 48 з 89 хворих, із яких у 39 вона була підвищеною на $2-3{ }^{\circ} \mathrm{C}-$ у 32 з 35 пацієнтів із деструктивним апендицитом та у 7 з $32-$ з деструктивним холециститом, а у 9 хворих з причини збільшеного живота та вираженого жирового шару (складки жирового шару) метод був неінформативний.

За даними УзД органів черевної порожнини, встановлено прямі та непрямі ознаки запального процесу в черевній порожнині. Поміж тим інформативність методу візуалізації залежала від кількості повітря у просвіті кишечнику. УЗД проведено у 81 з 89 хворих, з яких при деструктивному апендициті - у 35 3 35, при деструктивному холециститі - у 32 з 32, при перфоративній виразці шлунка та дванадцятипалої кишки - у 14 з 22 хворих.

При деструктивному апендициті візуалізація здійснена у 68 з 74 пацієнтів, з яких апендикулярний абсцес - у 15 з 16 та апендикулярний інфільтрат - у 18 з 19. Типова локалізація червоподібного відростка виявлена у 22, медіальне розташування у 6, підпечінкове - у 7 хворих. Встановлені непрямі УзД-ознаки при деструктивному апендициті: вільна рідина по правому фланку з включеннями - у 32, в ділянці кореня брижі кишечнику - у 8, набряк стінки тонкого кишечнику - у 29, зниження перистальтики кишечнику - у 28, локальна прискорена перистальтика - у 3, збільшення та набряк брижових лімфатичних вузлів - в усіх 35 хворих. Допплерографічне дослідження показало збільшення кровотоку в інфільтрованих тканинах великого чепця та стінках кишки у 19 з 35 хворих.

УзД жовчного міхура проведено в усіх 32 пацієнтів досліджуваної групи. Встановлено наявність конкрементів у просвіті жовчного міхура - у 12, набряк стінки жовчного міхура $>5$ мм - у 30, наявність газу у стінці - у 21, позитивний ультрасонографічний симптом Мерфі - в усіх 32, збільшення жовчного міхура - у 31, зміни у просвіті жовчного міхура (осад) у 15, скупчення рідини навколо жовчного міхура - у 24 
та інфільтративний перевезикальний процес - у 8 пацієнтів. Кольорове дуплексне картування проведено у 13 з 32 пацієнтів. Встановлено порушення кровообігу у стінці жовчного міхура, а також посилення кровообігу в інфільтративно зміненому великому чепці.

УзД проведено у 11 з 22 хворих з перфоративною виразкою шлунка та дванадцятипалої кишки і було інформативним у 5 пацієнтів із візуалізацією вільної рідини в порожнині малого тазу та по фланках, але у 6 пацієнтів через велику кількість повітря візуалізувати чіткі межі інфільтративного утворення не вдалося.

Рентгенологічне дослідження органів черевної порожнини у хворих з деструктивним апендицитом проведено через підозру на непрохідність кишечнику (вертикальна позиція) у $10 з 35$ пацієнтів. Виявлено парез кишечнику на тлі запального процесу у вигляді рівнів рідини у просвіті тонкого кишечнику у 8 пацієнтів. Оглядова рентгенографія виконана у 5 з 32 хворих із деструктивним холециститом, 3 яких в усіх 5 хворих візуалізовані конкременти. Оглядова рентгенографія виконана у 22 хворих із перфоративною виразкою шлунка та дванадцятипалої кишки, з яких вільне повітря різної кількості під куполами діафрагми встановлено у 17 хворих.

3 метою верифікації захворювання та прискіпливої візуалізації патологічного процесу у черевній порожнині проведено КТ у 16 хворих, з яких 5 - з перфоративною виразкою шлунка та дванадцятипалої кишки з причини неінформативності оглядової рентгенографії (відсутності повітря) та у $11-3$ метою диференційної діагностики підпечінкового деструктивного апендициту. За даними КТ, візуалізовані перфоративна виразка препілоричного відділу, а також підпечінкове розташування червоподібного відростка.

\section{Обговорення}

Обговорення доцільно почати з даних протоколу Міністерства охорони здоров'я України «Гострий апендицит» (2016р.) та колективної роботи авторів посібника «Невідкладна хірургія органів черевної порожнини (стандарти організації та професійно орієнтовані алгоритми надання медичної допомоги)» за редакцією П.Д. Фоміна та співавторів (2018), де вказано, що при деструктивному апендициті частка пацієнтів, госпіталізованих пізніше, ніж через 24 год з початку захворювання, становить 4,9-31,2\%, а післяопераційна летальність серед них - 0,15\% $(0-0,4 \%)[2]$.

Тому в дослідження були включені пацієнти, госпіталізовані пізніше, ніж через 24 год від початку захворювання, що мали ускладнений перебіг із проявами як інфільтратів, так і абсцесів черевної порожнини. При гострому апендициті, за даними S. Di Saverio (2020), частота перфорації коливається в межах 16-40\% з більш високими показниками в молодших вікових групах (40$57 \%)$ і у пацієнтів віком $>50$ років (55-70\%). Сьогодні відводять значну роль діагностичній візуалізації апендициту: УзД, КТ та МРТ. Такі післяопераційні ускладнення, як ранова інфекція, інтраабдомінальний абсцес, кишкова непрохідність, становлять до $11,1 \%$ [3].

Аналіз методів візуалізації гострого апендициту представлено в роботі S. Di Saverio (2020), в якій зазначено, що загальна чутливість та специфічність методу УзД становить 76 та 95\%, КТ 99 та 84\% відповідно [3, 15]. За даними J.M. Fields та співавторів (2017), позитивна та негативна прогностична цінність становить 91 та 94\% відповідно [16]. Натомість в роботі R. Sola та співавторів (2018) вказано, що після прийняття діагностичного алгоритму, в якому було пріоритетом УЗД, а не КТ, та включено стандартні шаблони обстеження, частота невизначених результатів знизилася з 44,3 до 13,1\%, а позитивних результатів, відповідно, збільшилася з 46,4 до $66,1 \%$ у пацієнтів із гострим апендицитом [17]. Незважаючи на різнобічні результати в точності діагностики гострого апендициту, основним недоліком УзД $\epsilon$ частота невізуалізації апендиксу, яка, за даними L. Segev та співавторів (2016), становить 34,1-71\% при позитивних результатах при подальшому лікуванні патології [18]. 32011 р. існує три метааналі- зи, в яких представлено використання МРТ при гострому апендициті в період вагітності з такими результатами: чутливість 90,5; 94 і 91,8\%; специфічність 98,6; 97 і 97,9\%; позитивна прогностична цінність 86,3\% і негативна прогностична цінність 99,0\% відповідно $[3,19]$.

При перфоративній виразці шлунка та дванадцятипалої кишки, за даними K. Anbalakan та співавторів (2015), при проведенні рентгенографічного обстеження органів грудної та черевної порожнини у вертикальному положенні вільне повітря під куполами діафрагми виявлено у 59,8\% хворих [20]. При відсутності вільного повітря Н.С. Кіт та співавтори (2014) рекомендують проведення КТ, оскільки ї̈ діагностична точність досягає $98 \%[21]$.

у нещодавно опублікованому Кокрейнівському систематичному огляді КТ для діагностики гострого апендициту у дорослих пацієнтів виявлено 64 дослідження, що включало 71 окремо досліджувану групу з загальною кількістю учасників 10280 (4583 з та 5697 - без гострого апендициту). Сумарна чутливість КТ становила 0,95, сумарна специфічність 0,94 [19]. При середній поширеності гострого апендициту $(0,43)$ ймовірність його наявності після позитивного результату КТ становила 0,92, а ймовірність гострого апендициту після негативного результату КТ - 0,04. В аналізах підгруп відповідно до посилення контрасту сумарна чутливість була вище для КТ з внутрішньовенним введенням контрастної речовини $(0,96)$, КТ з ректально введеною контрастною речовиною $(0,97)$ і КТ з внутрішньовенним та пероральним введенням контрастної речовини $(0,96)$, ніж для КТ без посилення $(0,91)$. Таким чином, сумарна чутливість КТ з низькою дозою $(0,94)$ була аналогічною сумарній чутливості КТ зі стандартною або неуточненою дозою $(0,95)$. Сумарна специфічність КТ з низькою дозою та стандартною чи неуточненою дозою не відрізнялися [3].

У збірному повідомленні у підрозділі щодо УзД холециститу M. Pisano та співавтори (2020) та J.C. Ra та співавтори (2018) опублікували дані 8 досліджень, які підтвердили неоднорідність діагностичних значень, діагностичного індексу та стандартних посилань для остаточного діагнозу. У цьому повідомленні зазначено, що традиційно для США представлені широкі діапазони чутливості (26-100\%), специфічності (62-88,1\%), позитивне та негативне прогнозне значення (3593,7\% та 52-97,1\% відповідно). Також вказано про глобальну точність УЗД, яка коливалася в межах 70,1-79\% [3, 22]. У цьому повідомленні представлено дослідження, яке проведено при відсутності жовчнокам'яної хвороби, що використано для виключення діагнозу гострого холециститу. Чутливість спрощеного визначення позитивного ультрасонографічного тесту становила 100\% порівняно зі стандартним визначенням, тобто наявність конкрементів у жовчному міхурі та принаймні однієї з УЗД-ознак гострого холециститу (чутливість 87\%, специфічність 82\%).

S. Martellotto та співавтори (2020) презентують результати проведення холецистектомії у 341 пацієнта. Автори встановили, що УзД має найкращу чутливість порівняно з КТ - 79,4 та 52,3\% відповідно, але меншу специфічність - 61,5 і 92,3\% відповідно. Встановлено позитивну інформацію стосовно ускладненого холециститу, показники якого кращі при КТ, ніж при УзД (відношення правдоподібності (likelihood ratio) 7,8 та 1,0 відповідно). КТ та УЗД еквівалентні для діагностики гострого холециститу, але КТ більш ефективне для діагностики складних та ускладнених випадків (індекс Юдена (Youden index) 0,3 та 0,001 відповідно) [23].

Використання КТ органів черевної порожнини та таза з метою верифікації захворювання проводять та вивчають з часу запровадження цієї методики. B.A. Urban, E.K. Fishman (2000) показана інформативність спіральної КТ, яка забезпечує швидкий та надійний спосіб верифікації абдомінальної хвороби в ургентній ситуації. На думку авторів, спіральна КТ може дати точний діагноз у більшості пацієнтів, включаючи гострий апендицит, холецистит та спайкову непрохідність [24]. Натомість А. Payor та співавторами (2015) доведена ефективність неконтрастної КТ органів 
черевної порожнини та таза з метою верифікації гострого болю в животі у відділенні невідкладної допомоги на основі обстеження 72 пацієнтів. Зазначено, що частота невдач становила 0 (0\%), 33 (46\%) пацієнти мали негативні дані КТ, 39 (54\%) - позитивні, 41 (57\%) були госпіталізовані, 31 (43\%) виписані, 8 (11\%) — перенесли операцію на черевній порожнині, повторне контрастне КТ здійснено у 3 (4\%) пацієнтів [25].

Проте як KТ, так спіральна КТ, $\epsilon$ дороговартісними (але точними у більшості пацієнтів) методами обстеження, що потребує певного часу для проведення, а також наявності апаратів. Тому В.Ф. Рибальченко, Ю.Г. Демиденко (2018-2020) розробили, запатентували та запровадили при обстеженні хворих із інтраабдомінальними інфільтратами й абсцесами вимірювання температури передньої черевної стінки в усіх квадрантах інфрачервоним термометром. Власне метод $\epsilon$ інформативним та ефективним як 3 метою діагностики інтраабдомінальних гнійних захворювань, так і прогнозування післяопераційного перебігу (щоденне вимірювання температури в усіх відділах) та не потребує фінансових вкладень і може проводитися у приймальному відділенні черговим хірургом [11-14].

Поміж тим В.В. Скиба та співавтори (2017) з метою верифікації інтраабдомінальних інфільтратів та абсцесів надавали перевагу тим методам, які доступні в ургентній ситуації: УзД та рентгенологічне дослідження, а при відсутності інформації - КТ. На думку дослідників, зазначені методи $\epsilon$ високоінформативними і можуть бути проведені у приймальному відділенні $[26,27]$.

Підбиваючи підсумок щодо діагностики первинних та вторинних інтраабдомінальних ускладнень - абсцесів, інфільтратів, рідинних утворень, доцільно звернути увагу, що, незважаючи на значну кількість шкал та різних сучасних інформативних методів візуалізації, завжди необхідно враховувати терміновість проведення обстеження впродовж нетривалого часу, інформативність методу та безпеку для пацієнта. Тому вважаємо, що з урахуванням вищезазначеного доцільно при запальних та ускладнених процесах органів черевної порожнини починати з УзД-дослідження, доповнюючи його кольоровим дуплексним картуванням, а за результатами вирішувати питання доцільності проведення КТ чи спіральної КТ (безконтрастної чи контрастної). Встановлюючи показання та враховуючи інформативність променевих методів візуалізації інтраабдомінальних ускладнень, доцільно пам'ятати, чи не затягуємо ми час до проведення екстреної операції, адже це дослідження потребує певної підготовки та дообстеження.

\section{Висновки}

1. Встановлення правильного діагнозу в хірургічному приймальному відділенні, враховуючи ургентну ситуацію, $\epsilon$ вкрай складною проблемою, з урахуванням обмеженого часу, тому вибір послідовності використання інструментальних методів обстеження з урахуванням інформативності та безпеки $\epsilon$ вкрай важливим. 3 метою верифікації гострої інтраабдомінальної патології шкірна термометрія була інформативною у 39 з 48 хворих.

2. При верифікації перфоративної виразки шлунка та дванадцятипалої кишки у 17 з 22 хворих оглядова рентгенографія не була інформативною (відсутність вільного повітря під куполами діафрагми), що потребувало проведення КТ.

3. Дослідження органів черевної порожнини за допомогою Узд було інформативним у 48,1-73,5\% випадків залежно від патології (деструктивний апендицит, деструктивний холецистит) та розвитку ускладнень з чутливістю 58-84,5\% та специфічністю 69-89,3\%. Такі розбіжності пов'язані з постійним вдосконаленням методики проведення обстеження.

4. Проблема верифікації ургентних інтраабдомінальних захворювань потребує подальшого вивчення як поодинокого перебігу хвороби, так і при поєднанні двох та більше недуг.

Конфлікт інтересів: відсутній.

Conflict of interests: the authors declare no conflict of interests.
Список використаної літератури/References:

1. Ministry of Health of Ukraine (2016) Unified clinical protocol of emergency, primary and secondary (specialized) medical care. Acute appendicitis. Kyiv, 75 p. (In Ukr.).

2. Fomin P.D., Usenko O.Yu., Bereznytsky Ya.S. (Eds.) (2018) Emergency abdominal surgery (standards of organization and professionally oriented algorithms of medical care). Library «Health of Ukraine», Kyiv, 354 p. (In Ukr.).

3. Di Saverio S., Podda M., De Simone B. et al. (2020) Diagnosis and treatment of acute appendicitis: 2020 update of the WSES Jerusalem guidelines. World J. Emerg. Surg., 27(2020). https://doi.org/10.1186/s13017-020-00306-3

4. Duke E., Kalb B., Arif-Tiwari H. et al. (2016) A systematic review and meta-analysis of diagnostic performance of MRI for evaluation of acute appendicitis. Am. J. Roentgenol., 206: 508-517.

5. Pisano M., Allievi N., Gurusamy K. et al. (2020) 2020 World Society of Emergency Surgery updated guidelines for the diagnosis and treatment of acute calculus cholecystitis (https:// wjes.biomedcentral.com/articles/10.1186/s13017-020-00336-x).

6. Huffman J.L.,S Schenker S. (2010) Acute acalculous cholecystitis: a review. Clin. Gastroenterol. Hepatol., 8(1): 15-22. doi:10.1016/j.cgh.2009.08.034

7. Tarasconi A., Coccolini F., Biffl W.L. et al. (2020) Perforated and bleeding peptic ulcer: WSES guidelines. World J. Emerg. Surg. https://doi.org/10.1186/s13017-019-0283-9

8. Chung K.T., Shelat V.G. (2017) Perforated peptic ulcer — an update. World J. Gastrointest. Surg., 9(1): 1-12. doi: 10.4240/wjgs.v9.i1.1

9. Stoker J., van Randen A., Laméris W., Boermeester M.A. (2009) Imaging patients with acute abdominal pain. Radiology, 253(1):31-46. doi: 10.1148/radiol.2531090302

10. Li P.H., Tee Y.S., Fu C.Y. et al. (2018) The Role of Noncontrast CT in the Evaluation of Surgical Abdomen Patients. Am. Surg., 84(6): 1015-1021.

11. Ribalchenko V.F., Demidenko Yu.G. (2020) The method of measuring the temperature of the anterior abdominal wall. Ukrainian patent for a utility model. UA 139580 U MPK (2019.01) A61B 17/00. (In Ukr.).

12. Ribalchenko V.F., Demidenko Yu.G. (2020) Method for diagnosing purulent-septic diseases of abdominal organs by measuring axillary-abdominal coefficient. Ukrainian patent for a utility model. UA 142612 U MPK (2020.01) A61B 17/00 G01N 25/20. (In Ukr.).

13. Ribalchenko V.F., Demidenko Yu.G. (2019) Thermometric panel of the anterior abdominal wall and prognostic axillary-abdominal coefficient. Neonatol. Surg. Perinat. Med., 3(33): 86-94. Doi: 10.24061/2413-4260.IX.3.33.2019.5 (In Ukr.).

14. Ribalchenko V.F., Demidenko Yu.G., Yarmak S.Ya. (2018) Thermometric panel of the anterior abdominal wall in children with infiltrates, abscesses of appendicular origin and prognostic axillary-abdominal coefficient. Surg. Pediatr., 2(59): 96. (In Ukr.).

15. Chang S.T., Jeffrey R.B., Olcott E.W. (2014) Three-step sequential positioning algorithm during sonographic evaluation for appendicitis increases appendiceal visualization rate and reduces (T use. Am. J. Roentgenol., 203: 1006-1012.

16. Fields J.M., Davis J., Alsup C. et al. (2017) Accuracy of point-of-care ultrasonography for diagnosing acute appendicitis: a systematic review and meta-analysis. Acad. Emerg. Med., 24: 1124-1136.

17. Sola R., Theut S.B., Sinclair K.A. et al. (2018) Standardized reporting of appendicitis-related findings improves reliability of ultrasound in diagnosing appendicitis in children. J. Pediatric. Surg., 53: 984-987.

18. Segev L., Segev Y., Rayman S. et al. (2016) The diagnostic performance of ultrasound for acute appendicitis in pregnant and young nonpregnant women: a case-control study. Int. J. Surg., 34:81-85.

19. Rud B., Olafsson L., Vejborg T.S. et al. (2019) Diagnostic accuracy of computed tomography for appendicitis in adults. Cochrane Database Syst. Rev. https://doi.org/10.1002/14651858. CD009977

20. Anbalakan K., Chua D., Pandya G.J., Shelat V.G. (2015) Five year experience in management of perforated peptic ulcer and validation of common mortality risk prediction models - are existing models sufficient? A retrospective cohort study. Int. J. Surg., 14: 38-44.

21. Kim H.C., Yang D.M., Kim S.W., Park S.J. (2014) Gastrointestinal tract perforation: evaluation of MDCT according to perforation site and elapsed time. Eur. Radiol., 24: 1386-1393.

22. Ra J.C., Lee E.S., Park H.J. et al. (2018) Efficacy of Superb Microvascular Imaging for Diagnosing Acute Cholecystitis: Comparison with Conventional Ultrasonography. Ultrasound Med. Biol., 44(9): 1968-1977.

23. Martellotto S., Dohan A., Pocard M. (2020) Evaluation of the CT Scan as the First Examination for the Diagnosis and Therapeutic Strategy for Acute Cholecystitis. World J. Surg., 44: 1779-1789. https://doi.org/10.1007/s00268-020-05404-6

24. Urban B.A., Fishman E.K. (2020) Targeted helical CT of the acute abdomen: appendicitis, diverticulitis, and small bowel obstruction. Semin. Ultrasound CT MR, 21(1): 20-39. doi: 10.1016/50887-2171(00)90011-8 
25. Payor A., Jois P., Wilson J. et al. (2015) Efficacy of Noncontrast Computed Tomography of the Abdomen and Pelvis for Evaluating Nontraumatic Acute Abdominal Pain in the Emergency Department. J. Emerg. Med., 49(6): 886-892. doi: 10.1016/j.jemermed.2015.06.062

26. Skiba V.V., Rybalchenko V.F., Ivanko O.V. et al. (2017) Surgical treatment of inflammatory and adhesive processes of the abdominal cavity in adolescents using a jet hydro scalpel. Child Health 12(1): 68-74. (In Ukr.).

27. SkibaV.V., RybalchenkoV.F., Ivanko O.V. etal. (2017) Surgical treatment of abdominal infiltrates in adolescents using a hydro jet scalpel. Pediatr. Surg., 1:32-38. (In Rus.).

\section{Modern imaging technologies in the diagnosis of primary intra-abdominal complications in patients}

\section{V.V. Skyba 1, 3, 4, V.F. Rybalchenko 2,3, O.V. Ivanko 1, 3, 4, A. Dar Yasin ${ }^{3}$}

'O.O. Bogomolets National Medical University, Kyiv, Ukraine

${ }^{2}$ Shupyk National Healthcare University of Ukraine, Kyiv, Ukraine

${ }^{3}$ Private higher education institution «Kyiv

Medical University», Kyiv, Ukraine

${ }^{4}$ Communal non-profit enterprise «Kyiv City

Clinical Hospital № 1», Kyiv, Ukraine

Abstract. Purpose: to improve the results of treatment of patients with primary intra-abdominal complications through the introduction of the latest informative imaging methods. Research methods: 191 patients with primary intra-abdominal infiltrates, abscesses and fluid formations were treated in the clinic of the Department of Surgical Diseases № 1, on the basis of the Surgery Center of Kyiv City Clinical Hospital № 1 from 2006 to 2019. The age of patients ranged from 16 to 85 years. Patients were divided into two groups: control group (2006-2012) 0151102 (53.4\%), and the study group (2013-2019) $89(46.6 \%)$ patients. Examination methods: radiography, ultrasound, computed tomography. Results. The causes of primary intra-abdominal complications were: complicated forms of appendicitis in 74 (38.7\%), perforated gastric and duodenal ulcer in 48 (25.1\%), compli-

\footnotetext{
Відомості про авторів:

Скиба Володимир Вікторович — доктор медичних наук, професор, заслужений діяч науки і техніки України, лауреат Державної премії України в галузі науки і техніки, академік Академії наук вищої школи України, директор Центру хірургії КНП «Київська міська клінічна лікарня № 1», завідувач кафедри хірургічних хвороб № 1 ПВН3 «Київський медичний університет», завідувач кафедри хірургії, анестезіології та інтенсивної терапії Інституту післядипломної освіти Національного медичного університету імені 0.0. Богомольця, Київ, Україна.

Рибальченко Василь Федорович — доктор медичних наук, професор кафедри дитячої хірургії Національного університету охорони здоров'я України імені П.Л. Шупика, професор кафедри хірургічних хвороб № 1 ПВНЗ «Київський медичний університет», Київ, Україна.

Іванько Олександр Вікторович - кандидат медичних наук, доцент, заслужений лікар України, директор КНП «Київська міська клінічна лікарня № 1», доцент кафедри хірургії, анестезіології та інтенсивної терапії Інституту післядипломної освіти Національного медичного університету імені 0.0. Богомольця, доцент кафедри хірургії № 1 ПВНЗ «Київський медичний університет», Київ, Україна.

Дар Ясін Ахмед — дисертант кафедри хірургічних хвороб № 1 ПВНЗ «Київський медичний університет», Київ, Україна.
}

Адреса для кореспонденції:

Рибальченко Василь Федорович

02000, Київ, вул. Бориспільська, 2

E-mail: pedsurgery_ua@ukr.net cated forms of cholecystitis in 69 (36.1\%). In the control group, an overview regeneration of the abdominal and thoracic cavity was performed with the clinic of perforated gastric and duodenal ulcer, as well as in patients with suspected intestinal obstruction on the background of an inflammatory process. Analysis of the data of $26 \mathrm{pa}-$ tients showed that in 6 patients there was no free air in the abdominal cavity. In the study group of patients, the cutaneous temperature of the anterior abdominal wall was measured in 48 patients, of whom in 39 patients it was increased by $2-3^{\circ} \mathrm{C}$. According to the ultrasound of the abdominal cavity, direct and indirect signs of the inflammatory process were established. Ultrasound was performed in 81 of 89 patients, of which with destructive appendicitis in 35 , destructive cholecystitis in 32 and with perforated gastric and duodenal ulcer in 14 patients. The visualization was established in 68 patients with destructive appendicitis, of which appendicular abscess in 15 and appendicular infiltration in 18 patients. Localization of the appendix according to ultrasound data: typical - in 22, medial - in 6 and subhepatic - in 7 patients. Ultrasound of the gallbladder was performed in 32 patients, and established changes indicated an inflammatory process. Radiography was performed in 22 patients with perforated gastric and duodenal ulcer, of which free air was found in 17 patients. Computed tomography was performed in 16 patients. Conclusions. In order to verify acute intra-abdominal pathology, skin thermometry was informative in 39 of 48 patients. When verifying a perforated gastric and duodenal ulcer in 17 of 22 patients, radiography was not informative, which required computed tomography. The study of the abdominal cavity using ultrasound was informative from $48.1 \%$ to $73.5 \%$ depending on the pathology (destructive appendicitis, destructive cholecystitis) and the development of complications with sensitivity from 58 to $84.5 \%$ and specificity from 69 to $89.3 \%$. Such discrepancies are associated with the constant improvement of the survey methodology.

Key words: appendicitis, cholecystitis, perforated gastric and duodenal ulcer, diagnostics, ultrasound, radiography, computed tomography, magnetic resonance imaging.

\section{Information about the authors:}

Skyba Volodimir V. — Doctor of Medical Sciences, Professor, Honored Worker of Science and Technology of Ukraine, Laureate of the State Prize of Ukraine in Science and Technology, Academician of the Academy of Sciences of Ukraine, Director of the Surgery Center of Kyiv City Clinical Hospital № 1, Head of the Department of Surgical Diseases № 1 Kyiv Medical University, Head of the Department of Surgery, Anesthesiology and Intensive Care of the Institute of Postgraduate Education of the 0.0. Bogomolets National Medical University, Kyiv, Ukraine.

Rybalchenko Vasyl F. - Doctor of Medical Sciences, Professor of the Department of Pediatric Surgery of the Shupyk National Healthcare University of Ukraine, Professor of the Department of Surgical Diseases № 1, Kyiv Medical University, Kyiv, Ukraine.

Ivanko Olexandr V. - Candidate of Medical Sciences, Associate Professor, Honored Doctor of Ukraine, Director of the Kyiv City Clinical Hospital № 1, Associate Professor of the Department of Surgery, Anesthesiology and Intensive Care of the Institute of Postgraduate Education of the 0.0. Bogomolets National Medical University, Associate Professor of Surgery № 1 Kyiv Medical University, Kyiv, Ukraine.

Dar Yasin Ahmed — dissertation of the Department of Surgical Diseases № 1, Kyiv Medical University, Kyiv, Ukraine.

Address for correspondence:

Vasyl Rybalchenko

02000, Kyiv, Boryspilska str., 2

E-mail: pedsurgery_ua@ukr.net 